\title{
The Partial Deinstitutionalization of Affirmative Action in U.S. Higher Education, 1988 to 2014
}

\author{
Daniel Hirschman, ${ }^{a}$ Ellen Berrey ${ }^{b}$
}

\author{
a) Brown University; b) University of Toronto
}

\begin{abstract}
Since the 1990s, affirmative action opponents have targeted colleges' and universities' race-conscious admissions policies and secured bans on the practice in eight states. Although scholarly and media attention has focused on these dynamics at a handful of elite institutions, little is known about race-conscious admissions across the broader field of higher education. We provide a descriptive, quantitative account of how different types of colleges and universities responded to this political context. Through analysis of almost 1,000 selective colleges and universities, we find a dramatic shift in stated organizational policy starting in the mid-1990s. In 1994, 60 percent of selective institutions publicly declared that they considered race in undergraduate admissions; by 2014, just 35 percent did. This decline varied depending on status (competitiveness) and sector (public or private). Race-conscious admissions remain the stated policy of almost all of the most elite public and private institutions. The retreat from race-conscious admissions occurs largely among schools lower in the status hierarchy: very competitive public institutions and competitive public and private institutions. These patterns are not explained by implementation of state-level bans. We suggest that the anti-affirmative action movement had a diffuse impact whose effects varied across different strata of American higher education.
\end{abstract}

Keywords: organizations; race; admissions

Citation: Hirschman, Daniel, and Ellen Berrey. 2017. "The Partial Deinstitutionalization of Affirmative Action in U.S. Higher Education, 1988 to 2014." Sociological Science 4: 449-468.

Received: June 21, 2017

Accepted: July 28, 2017

Published: August 28, 2017

Editor(s): Jesper Sørensen, Sarah Soule

DOI: $10.15195 / \mathrm{v} 4 . \mathrm{a} 18$

Copyright: (C) 2017 The Author(s). This open-access article has been published under a Creative Commons Attribution License, which allows unrestricted use, distribution and reproduction, in any form, as long as the original author and source have been credited. (C) (i)
$\mathrm{R}$ ACE-conscious admissions policies came under coordinated political attack starting in the early 1990s and remain controversial today. The educational institutions targeted, such the University of Michigan and Princeton University, are widely viewed as the cradle of society's elites. Scholarly attention has largely mirrored these political and legal controversies. The organizational research literature on race-conscious admissions policies has focused on the most elite private and public institutions (Lipson 2001; Lipson 2007; Berrey 2015; Hirschman, Berrey, and Rose-Greenland 2016), which were the first to adopt race-conscious admissions (Karabel 2005; Stulberg and Chen 2014). With a handful of exceptions (e.g., Grodsky and Kalogrides 2008), this research tends to infer the logic of the entire field of higher education from analyses of the admissions practices of elite institutions. However, the use of race-conscious admissions policies and the effects of political contention may vary across the field.

To grapple with the dynamics of race-conscious admissions across a broader segment of higher education, we analyze the publicly declared admissions practices of approximately 1,000 U.S. colleges and universities with selective admissions practices. These schools enroll approximately 35 percent of all undergraduates. ${ }^{1}$ They include virtually all schools that reject more than 15 percent of applicants. We distinguish the schools in our population according to their status, as measured by Barron's Profiles of American Colleges: Most Competitive, Highly Competitive, Very 
Competitive, and Competitive. Our primary analysis focuses on a school's stated consideration of race in undergraduate admissions. Our dependent variable comes from a battery of standardized questions collected annually by the College Board and distributed to the public by the College Board and outlets such as U.S. News $\mathcal{E}$ World Report. ${ }^{2}$ Given the prominence of the fight over the continued use of race in admissions, we investigate how these selective institutions' public commitments to considering race changed between 1988 and 2014.

As we show, in 1994, 60 percent of institutions publicly declared that they considered race in undergraduate admissions; by 2014, just 35 percent did. School status and sector (public or private) are key factors. Despite being the explicit targets of anti-affirmative action mobilizations, elite universities did not waver in their declared policy of considering race in admissions. In contrast, many lower-status selective schools stopped signaling that they considered race. These dynamics vary somewhat by institutional sector; public schools abandoned affirmative action policies at faster rates than private schools in the intermediate strata. These results are not explained by state-level prohibitions on affirmative action. In other words, we find that the diversity imperative, when measured by a public commitment to considering race in admissions, has been partially deinstitutionalized in the field of U.S. higher education.

In the following sections, we review the institutionalization and contested legitimacy of race-conscious admissions at elite schools. We then discuss what is not known about affirmative action policy nationally. Next, we turn to our data, methods, and results. We conclude with a discussion of the reasons why status differences best explain the uneven decline in race-conscious admissions.

\section{The Institutionalization and Contested Legitimacy of Affirmative Action}

Race-conscious affirmative action in admissions (or affirmative admissions, cf. Skrentny 2002) consists of college and university-level policies and programs for recruiting, admitting, and matriculating students of color, most significantly African Americans but also Latinos and Native Americans. Affirmative admissions is an accommodationist strategy used by predominantly white selective colleges and universities, where white and wealthy students are overwhelmingly favored in admissions. Early rhetorical justifications emphasized remedying racial inequality and advancing black progress (Karabel 2005, Berrey 2015). Today, the prevailing justification for affirmative admissions emphasizes the educational benefits of increased student diversity.

The history of affirmative admissions policies in the United States has been characterized by visible support from elite institutions, growing resistance by an oppositional conservative movement, and a series of court decisions that have not satisfied opponents but nonetheless narrowed the parameters of acceptable policy. Race-conscious admissions practices were first voluntarily adopted in the early 1960s by prestigious universities in the north, where top administrators took inspiration from the Southern civil rights movement's challenge to deep-seated racial 
inequalities (Stulberg and Chen 2014). By 1972, affirmative admissions for black students was commonly practiced at predominantly white selective colleges and universities (Grodsky 2007). The first major U.S. Supreme Court case challenging affirmative admissions, Regents of the University of California v. Bakke (1978), resulted in a complicated decision: race-conscious admissions was acceptable but racial quotas were not. After Bakke, universities and colleges continued to practice affirmative action apace, and admissions professionals at numerous elite universities developed a consensus that it was an essential technique of diversity management (Lipson 2007).

Yet the legitimacy of affirmative action-whether key stakeholders perceive it as necessary or unnecessary, valuable or hazardous (Suchman 1995)—has remained legally and politically contentious. In the 1980s, eliminating affirmative action became a political objective for conservative operatives (Kelly and Dobbin 1998). These opponents developed a robust network of institutions and supports for this effort, including public interest law firms, foundations, and think tanks (Okechukwu forthcoming). In the movement's first major admissions case, Hopwood v. University of Texas (1996), the Fifth Circuit court found that race-conscious admissions could not be voluntarily used in Texas, Louisiana, and Mississippi. ${ }^{3}$ Subsequently, through ballot initiatives, statutes, and gubernatorial executive orders, advocates achieved state-level bans on public institutions' use of affirmative admissions in eight states, beginning with California in the mid-1990s and then Washington (1998), Florida (1999), Michigan (2006), Nebraska (2008), Arizona (2010), New Hampshire (2011), and Oklahoma (2013). Private institutions were not directly affected by these state-level bans.

In two cases filed by anti-affirmative action activists against the University of Michigan, Gratz v. Bollinger and Grutter v. Bollinger (2003), the U.S. Supreme Court affirmed that colleges and universities could consider applicants' racial status in the admissions process through an individualized review for the purposes of achieving the educational benefits of diversity. The Grutter ruling overturned Hopwood, whereas Gratz found that Michigan's heavily quantified undergraduate admissions system was not constitutional. In 2013 and again in 2016, the Supreme Court upheld Grutter in cases against the University of Texas but seemed to heighten the burden on admissions offices to ensure that "race plays no greater role than is necessary." Meanwhile, state-level bans remained lawful, as the Supreme Court affirmed in Schuette v. Coalition to Defend Affirmative Action (2014). Beyond these headline court cases, activists have also recently challenged admissions policies at elite universities like Rice and Princeton through the U.S. Office of Civil Rights.

These political and legal contests contributed to a context of contentious legitimacy: race-conscious admissions were both permissible to employ and permissible to forbid. Organized challenges to the policy continue, with ongoing legal cases against Harvard University and the University of North Carolina, among others. ${ }^{4}$ Because of these developments, race-conscious admissions have been partially deinstitutionalized: there have been successful challenges to taken-for-granted understandings of this institutionalized practice and large-scale organizational abandonment of it (on deinstitutionalization, see Oliver 1992; Kelly and Dobbin 
1998). However, the extent of policy changes in higher education and the impact of direct political challenges have not been thoroughly understood to date.

\section{What We (Don't) Know about Affirmative Action Policies Nationally}

The institutionalization, contested legitimacy, and partial deinstitutionalization of affirmative admissions has motivated a robust body of quantitative scholarship. Almost all of this research infers the existence of race-conscious policy from studentlevel data by comparing the college application, enrollment, and graduation rates of different student groups (Bowen and Bok 1998; Espenshade, Chung, and Walling 2004; Grodsky 2007; Alon 2015). Studies are designed to capture the weight that admissions offices apparently give to applicants on the basis of their racial group or other social statuses such as athletic involvement and legacy (being closely related to alumni). A strong finding across studies is that affirmative admissions is especially effective at moving African American students into the most prestigious universities (Bowen and Bok 1998; Alon 2015). Another major finding is that bans on the consideration of race lower African American enrollments at top public schools (Long and Tienda 2008; Howell 2010; Garces 2012).

This scholarship rarely examines schools' internal practices or self-reports of whether they consider race in admissions. Instead, it follows one of two general research designs. One approach, which investigates population-based survey samples of students (e.g., Howell 2010), usefully measures the outcomes of political interventions, such as bans. Yet it provides very sparse institutional data, as even relatively large samples have small numbers of students attending any particular school. The other design draws samples from an (intentionally) unrepresentative sample of institutions (e.g., Bowen and Bok 1998). This approach provides richer institutional detail but tends to include only very elite schools.

These research designs do not capture an important dimension of admissions policy: colleges' and universities' public claims to be engaged in race-conscious admissions. Yet such information is essential for understanding the consequences of political opposition to the policy's legitimacy and legality. As institutional theorists have long observed, organizations' public commitments, in forms such as practices and policies, often serve as important signals of legitimacy within a shared organizational field (Meyer and Rowan 1977; Deephouse and Suchman 2008; Scott 2013). Without attending to changes in institutions' public commitments to affirmative action, existing research fails to capture the anti-affirmative action movement's full impact.

To our knowledge, the study by Grodsky and Kalogrides (2008) is the only prior national study of U.S. colleges' and universities' publicly declared use of affirmative admissions. Like our study, they analyze longitudinal panel data collected by the College Board in the Annual Survey of Colleges (ASC) on almost 1,300 public and private colleges and universities. They examine how institutional characteristics and context influence schools' propensity to self-report that they consider race in admissions. Their study generates three major relevant findings. First, slightly more 
than half of institutions in their sample self-reported that they used affirmative action in admissions between 1986 and 2003. Second, the percentage of institutions doing so declined over time, starting in 1996 with the first state ban. Third, Grodsky and Kalogrides (2008) found that sector (public or private) and prestige (measured as average SAT scores and real tuition and mandatory fees) are the most important influences on schools' propensity to self-report. They briefly noted that more prestigious institutions, both public and private, were more likely to publicly declare that they considered race in admissions (p. 24).

Our project builds on Grodsky and Kalogrides in two ways. First, we extend the empirical analysis to 2014, the most recent year for which data are available, to capture change following the 2003 Grutter decision and additional state bans. Second, we identify a crucial but overlooked source of variation in schools' public commitments to affirmative admissions: status. Status refers to a widely accepted ranking of organizations and organizational actors within a field on the basis of their distinctive characteristics (Deephouse and Suchman 2008:59). Status is "lumpy" and hierarchical; that is, status refers to groups that are clustered together by some set of shared characteristics (such as "The Ivy League" or "The Public Ivies"), and these groupings are situated in a vertical distinction to one another ("The Ivy League" has higher status than "The Public Ivies"). We operationalize status grouping through the widely recognized Barron's Profiles of American Colleges, a guidebook with tiered ranking that sorts schools into broad groupings according to their "competitiveness."

Our interest in status contrasts with Grodsky and Kalogrides' interest in prestige, which is based on continuous measures. ${ }^{5}$ Our approach makes visible changing regimes in the field of higher education that may be obscured theoretically by the continuity assumptions that follow from a focus on reputation and mathematically from the inclusion of continuous measures in regression models. Our attention to status is informed by the robust body of research on status differences across U.S. colleges and universities. As this scholarship demonstrates, the field of U.S. higher education is very hierarchical (Bastedo and Gumport 2003; Stevens, Armstrong, and Arum 2008; Posselt et al. 2012), and field-level practices and policies often differ according to school status (e.g., Levitsky and Armstrong 2017).

Following from this work, our analysis describes how variations in status and sector shape whether schools publicly commit to affirmative admissions. We expect that, in the context of contested legitimacy, differences in status groupings within the field would influence the deinstitutionalization of race-conscious admissions policy.

\section{Data and Methods}

We analyze the publicly-declared admissions policies of approximately 1,000 selective colleges and universities based on two data sources: the College Board's ASC and Barron's Profile of American Colleges. The ASC annually collects information on institutional characteristics, including admissions policies, from more than 3,000 colleges and universities. We analyze the annual data collected from 1988 to 2014 (27 years in total). The ASC includes all of the data requested as part of the "Common 


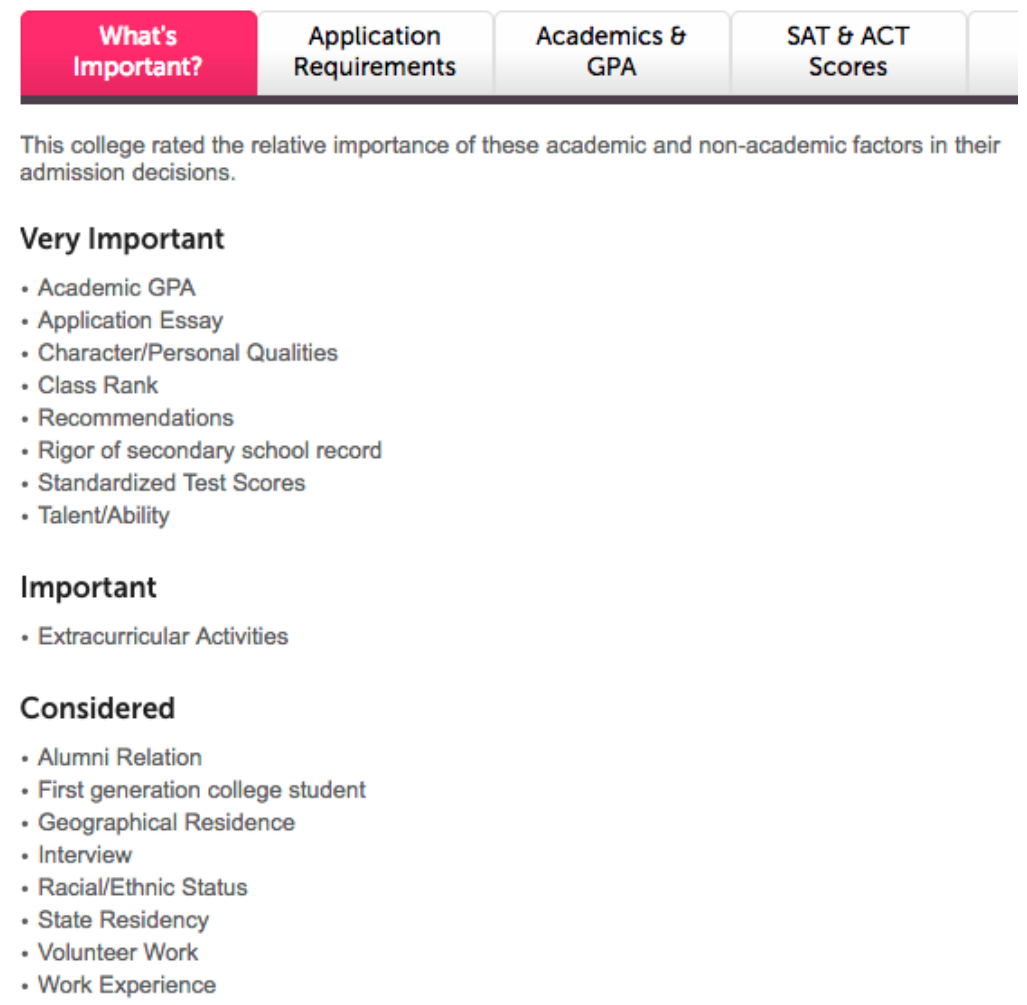

Figure 1: From Brown University's admissions profile on the College Board's BigFuture website.

Data Set Initiative" (www.commondataset.org) organized in 1996 by the College Board, Peterson's, and the U.S. News \& World Report to unify and standardize the collection of data from colleges and universities. Our primary dependent variable is colleges' and universities' stated consideration of race in admissions. This variable comes from a battery of questions in the ASC about what factors a university considers in the undergraduate admissions process. These factors are in turn promoted in guidebooks that explain the admissions process of individual schools to potential applicants. Figures 1 and 2 show examples of the contemporary presentation of this data on the College Board's BigFuture website. Figure 1 shows the admissions consideration list for Brown University; Figure 2 shows the comparable list for the University of Maine. Note how Brown lists "Racial/Ethnic Status" as a "Considered" variable, whereas the University of Maine does not list "Racial/Ethnic Status" anywhere. We use the ASC data to generate a dichotomous measure of the consideration of race that parallels this presentation: colleges are given a " 1 " if they say they categorize Racial/Ethnic Status as a "Considered," "Important," or "Very Important" factor and a " 0 " if they do not consider it. We have nearly complete data on this variable for all institutions in our sample for all 27 years.

In some sense, these data are "self-reports," but they are consequential selfreports that function as strategic and political organizational self-presentations rather than simply survey responses. ${ }^{6}$ This characteristic makes them especially 


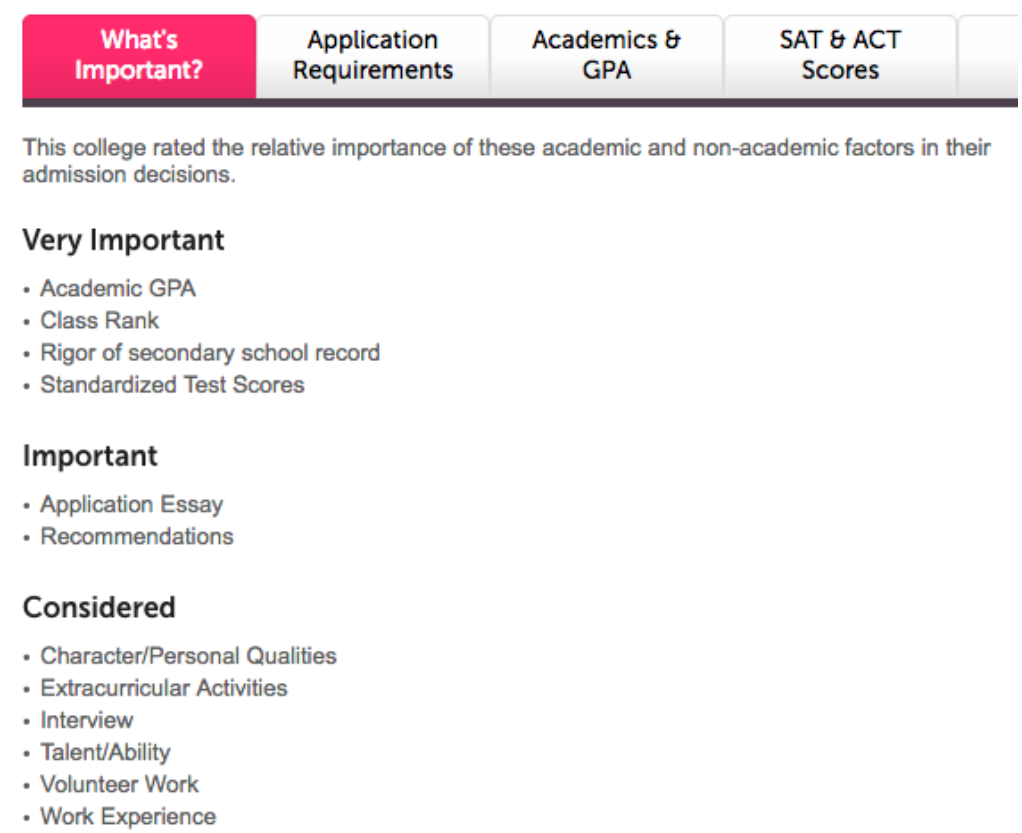

Figure 2: From The University of Maine's admissions profile on the College Board's BigFuture website.

suitable to an analysis of the changing legitimacy of institutional practices. We treat these declarations as a part of an organization's public commitment to diversity; we do not assume that they perfectly represent practices within the admissions office.

Our most important independent variable comes from Barron's rankings. Barron's measure of status divides colleges and universities into seven (nearly) hierarchical groupings based on SAT and/or ACT scores and class rank of entering students along with the institution's selectivity (percent of applicants accepted: "Most Competitive," "Highly Competitive," "Very Competitive," "Competitive," "Less Competitive," "Noncompetitive," and "Special"). These measures are widely used in the higher education literature. We focus our analysis on the first four categories, which in 2004 included 1,006 institutions. In 2004, two percent of all undergraduates were enrolled at Most Competitive, four percent at Highly Competitive, 10 percent at Very Competitive, and 19 percent at Competitive schools. ${ }^{7}$ Status is highly persistent in higher education, so for simplicity, we rely on the 2004 measures throughout our analysis, as that year is the midpoint of 1994 (the peak of the consideration of race) and 2014. ${ }^{8}$ We exclude Noncompetitive and Less Competitive schools, which generally accept more than 98 percent and 85 percent of applicants, respectively. These schools are sufficiently close to open enrollment as to make their self-reports less interesting politically and theoretically. We exclude Special schools, which include mostly undergraduate institutions dedicated to specialized professions such as music or art and design, because their idiosyncratic admissions practices are difficult to compare.

Other variables for our analysis include institutional sector (public or private), religious affiliation ("Nonreligious," "Catholic," "Non-Catholic Christian," and 
Table 1: Full sample descriptive statistics.

\begin{tabular}{lrr}
\hline & $N$ & Percent \\
\hline Total & 993 & 100.0 \\
Competitive & 587 & 59.1 \\
Very Competitive & 248 & 25.0 \\
Highly Competitive & 95 & 9.6 \\
Most Competitive & 63 & 6.3 \\
Public & 332 & 33.4 \\
Private & 661 & 66.6 \\
Nonreligious & 562 & 56.6 \\
Non-Catholic Christian & 298 & 30.0 \\
Catholic & 131 & 13.2 \\
Jewish & 2 & 0.2 \\
State Ban in 2014 & 158 & 15.9 \\
Considered Race in 1994 & 600 & 60.4 \\
Considered Race in 2014 & 352 & 35.4 \\
\hline
\end{tabular}

"Jewish"), the presence of a state-level affirmative action ban, and region (operationalized as circuit court districts, given the importance of court decisions). These groupings may capture both traditional regional effects and specific legal environments (e.g., courts' hostility to affirmative action), which are difficult to disentangle.

We approach our quantitative analysis as primarily a task of quantitative description, which is an invaluable component of sociological research on its own and an important precursor to any further analysis (Abbott 1998). We first analyze trends in the consideration of race by organizational status and by status and institutional sector. We then present simple linear probability regression models that predict the deinstitutionalization of schools' public commitments to race-conscious admissions. ${ }^{9}$ That is, we restrict our sample to institutions that stated they considered race in 1994 (the peak year) and predict the probability of these institutions abandoning that public commitment by 2014. We conduct these analyses for all states and also by restricting our sample to states with affirmative action bans.

\section{Analysis and Results}

Table 1 presents descriptive statistics on our full sample, which consists of 993 institutions (99 percent of schools ranked by Barron's in 2004, including every school in the top two tiers). About two-thirds of these schools are private, and 43 percent have some religious affiliation. About 60 percent stated that they considered race in admissions in 1994. Just 35 percent did so in 2014.

Figure 3 graphs the proportion of schools in each Barron's tier that self-reported considering race over the period of 1988 to 2014. Figure 4 graphs the same information, restricted to states that never passed a ban on the consideration of race. The patterns are the same, suggesting that the direct effect of bans does not explain these 


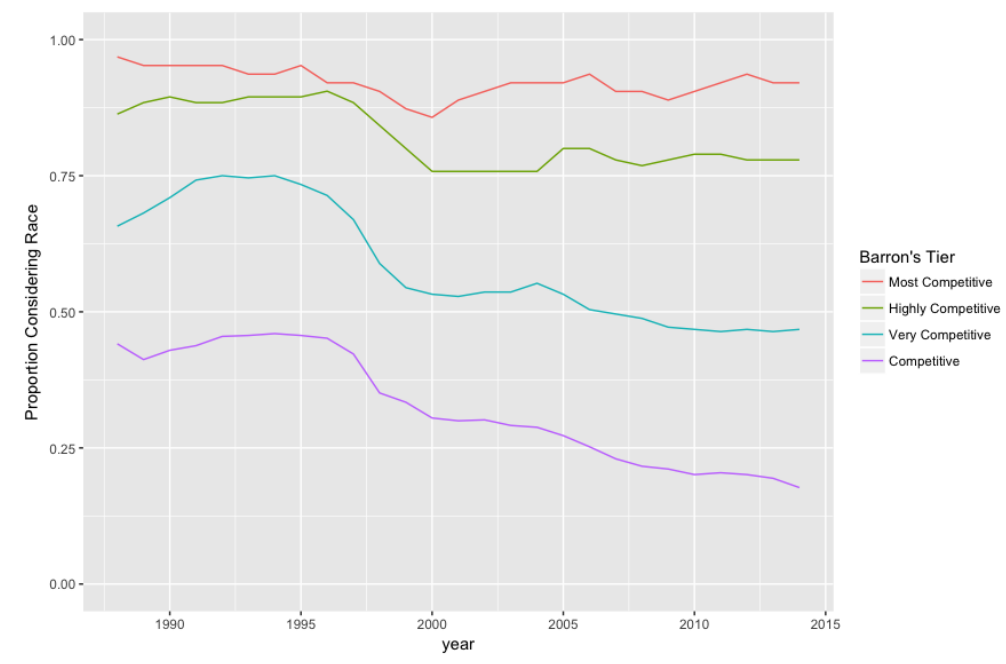

Figure 3: Proportion of colleges and universities considering race in admissions by Barron's tier.

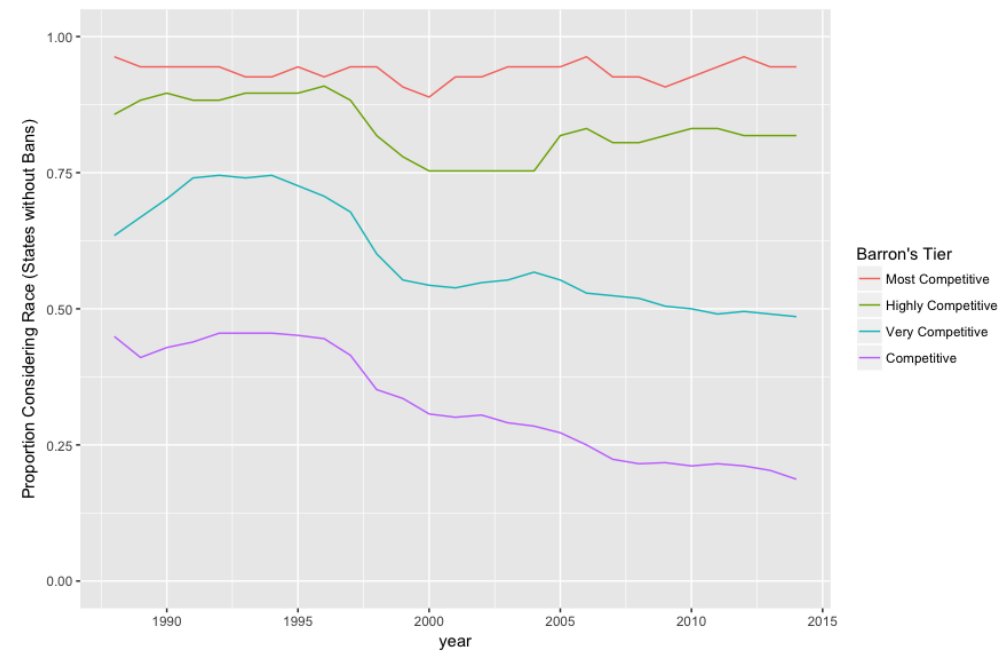

Figure 4: Proportion of colleges and universities considering race in admissions by Barron's tier in states that did not enact a ban.

movements. Among the Most Competitive schools, there was almost no decline in their public statements on race-conscious admissions. Three schools that considered race in 1994 did not in 2014. Two of them, the University of California, Berkeley and the University of California, Los Angeles, were required to do so by a state ban, whereas the private Davidson College abandoned race-conscious admissions absent such a requirement. Additionally, one Most Competitive school (Columbia University) adopted the consideration of race between 1994 and 2014. Overall, the use of race has been almost universal at this tier and relatively constant.

Highly Competitive schools displayed relatively more movement. In 1995, 91 percent of those schools considered race. This proportion substantially dipped in 


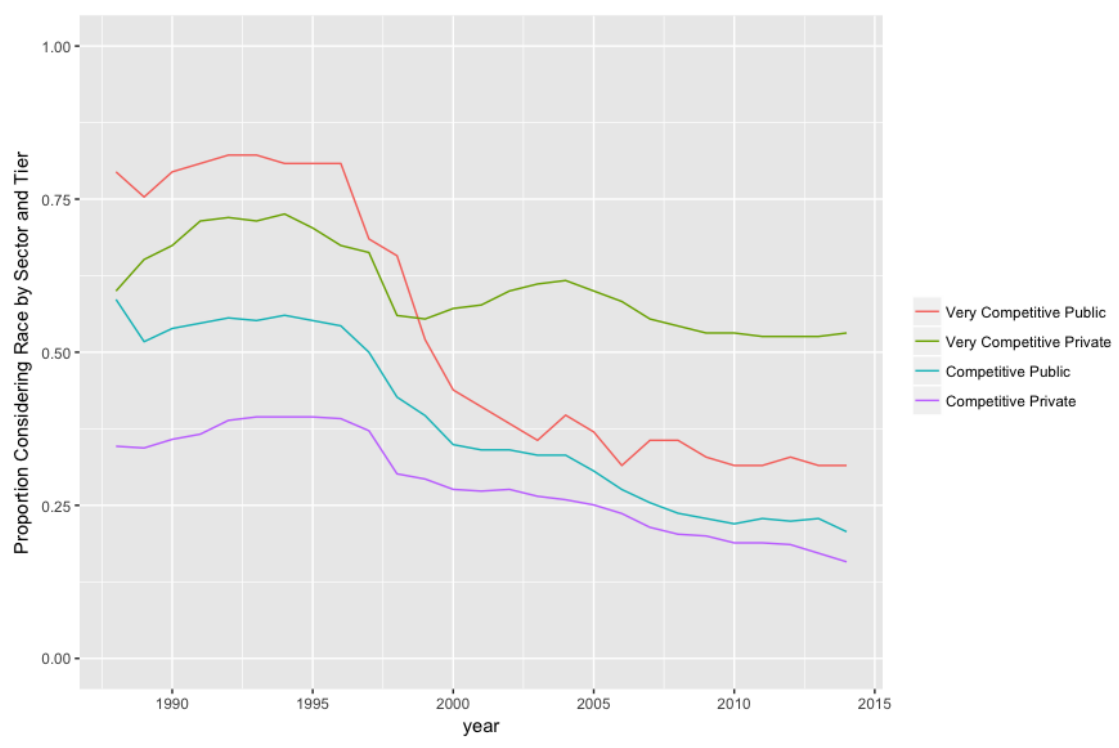

Figure 5: Proportion of colleges and universities considering race by sector and Barron's tier (Very Competitive and Competitive).

the late 1990s down to 76 percent and stabilized through 2014. Seventeen Highly Competitive schools that considered race in 1994 did not in 2014, including five public universities and colleges, four of which were in ban states (University of California, San Diego; Florida State University; University of Florida; and University of Michigan) and 12 private ones (such as Tulane University in Louisiana). State bans account for much of the decline among public institutions in this status tier, but most of the decline came from private schools under no legal obligation to change their admissions policies. Overall, there was a small divergence between Most Competitive and Highly Competitive schools, but both continued to use race in admissions at high rates and showed no signs of decline after 2003, coinciding with the Grutter decision.

Very Competitive and Competitive colleges and universities exhibited a much sharper decline in the rate at which they publicly reported considering race in admissions. Overall, 75 percent of Very Competitive schools reported doing so in 1994, compared with just 47 percent in 2014. In this period, the percentage of Competitive schools considering race fell from 46 percent to 18 percent.

Figure 5 examines this drop in more detail, separating out these tiers by institutional sector; Figure 6 provides the same information restricted to states that never banned the consideration of race. Both figures show a striking divergence between public and private schools in the Very Competitive tier. The percentage of Very Competitive public schools that considered race declined from a high of 82 percent in 1994 to just 32 percent in 2014-a remarkable drop of 50 percentage points. These include schools in states with bans, such as the University of California campuses at Davis, Santa Barbara, and Santa Cruz, along with schools in states without bans, such as the University of Kansas and the University of Illinois at Chicago. Restricting our attention to states without bans slightly mutes this trend, but Very 


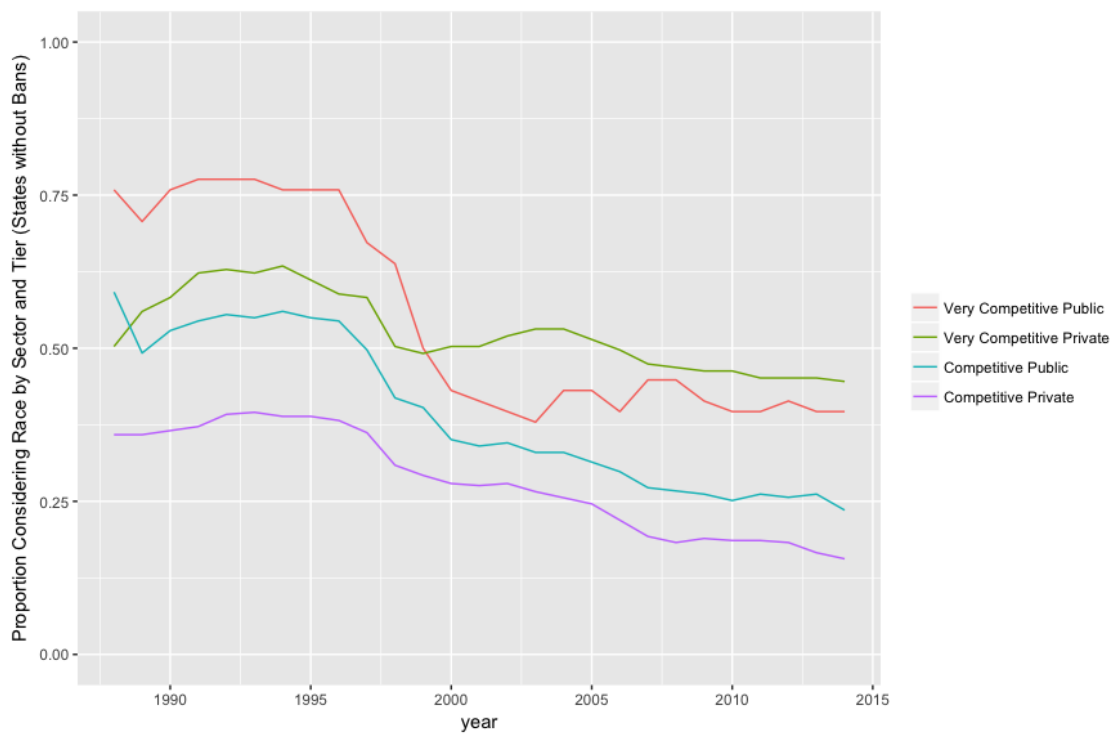

Figure 6: Proportion of colleges and universities considering race by sector and Barron's tier (Very Competitive and Competitive) in states that did not enact a ban.

Competitive schools still dropped 36 percentage points, from 76 percent in 1994 to 40 percent in 2014. Among Very Competitive private schools, such as Ripon College in Wisconsin and Baylor University in Texas, there was a more modest decline, from 73 percent in 1994 to 53 percent in 2014 and, for just those in states without bans, from 63 percent to 45 percent. Finally, Competitive colleges and universities saw significant declines but without the crossover pattern, dropping from 56 percent to 21 percent for publics and 39 percent to 16 percent for privates over this period. Examples of Competitive schools abandoning the use of race range from the public University of Central Arkansas to the private Pacific University in Oregon.

Together, Figures 3 and 5 show the widening gap between tiers, and the especially large decline for Very Competitive public schools. Figures 4 and 6 show that both patterns persist in states without bans on the consideration of race, suggesting that the direct effect of these bans cannot explain the trends.

The next set of analyses focuses specifically on colleges and universities that stated they considered race in 1994 and ceased doing so by 2014. Table 2 shows descriptive statistics. Of the 589 schools that considered race in 1994 and provided full data in the ASC, about 53 percent still considered race in 2014, and 47 percent $(N=278)$ no longer did. Although 101 of those 278 schools were in states with bans on race-conscious admissions, less than half $(n=42)$ were public, as Table 3 shows. These 42 public schools constituted about 15 percent of all schools that abandoned race by 2014, and thus 15 percent is the upper bound of the proportion of schools that abandoned the use of race that could possibly be explained directly by the state-level bans. The other 85 percent of schools that ended their stated commitment to race-conscious admissions did so in the absence of explicit legal mandates. How can we best describe these schools? 
Table 2: Schools considering race in 1994 (deinstitutionalization analysis sample).

\begin{tabular}{lrc}
\hline & $N$ & Percent \\
\hline Total & 589 & 100.0 \\
Competitive & 262 & 44.5 \\
Very Competitive & 183 & 31.1 \\
Highly Competitive & 85 & 14.4 \\
Most Competitive & 59 & 10.0 \\
Public & 206 & 35.0 \\
Private & 383 & 65.0 \\
Nonreligious & 359 & 61.0 \\
Non-Catholic Christian & 157 & 26.7 \\
Catholic & 73 & 12.4 \\
Jewish & 0 & 0.0 \\
State Ban in 2014 & 101 & 17.1 \\
Considered Race in 2014 & 311 & 52.8 \\
\hline
\end{tabular}

Table 3: Characteristics of colleges and universities that abandoned race-conscious admissions.

\begin{tabular}{lrr}
\hline & $N$ & Percent \\
\hline Total & 278 & 100.0 \\
Public, in Ban States & 42 & 15.1 \\
Public, not in Ban States & 82 & 29.5 \\
Private, in Ban States & 20 & 7.2 \\
Private, not in Ban States & 134 & 48.2 \\
\hline
\end{tabular}

In Table 4, we present the results of five linear probability models predicting the probability of a school that publicly declared its use of race in admissions in 1994 declaring that it did not use race in 2014 (abandoning, for short). Models 1-3 include all 589 schools that considered race in 1994 . We begin by looking at just status. Model 1 mirrors the results of Figure 3. Most Competitive schools are estimated to be 64 percent less likely to abandon the use of race than Competitive schools (the reference category). The model predicts just 5 percent of Most Competitive schools abandon, in contrast to 69 percent of Competitive schools. With the Barron's status variable alone, this model explains about 20 percent of the total variance.

Models 2 and 3 add additional covariates: institutional sector, religion, the presence of a state ban, and (in model 3) the regional and legal environment variables. Private and public schools are not evenly distributed across the status tiers, and thus in some sense sector might explain some of the divergence between tiers. But as model 2 shows, the sector variable is small in magnitude and not statistically significant. Similarly, religious schools do not exhibit a different pattern. The variables for both Catholic and other Christian schools are small and not significant. The state ban variable is significant in model 2; schools in ban states abandon at 
Table 4: Linear probability models predicting abandonment of race-conscious admissions between 1994 and 2014.

\begin{tabular}{|c|c|c|c|c|c|}
\hline & Model 1 & Model 2 & Model 3 & $\begin{array}{c}\text { Model } 4 \\
\text { (Privates) }\end{array}$ & $\begin{array}{l}\text { Model } 5 \\
\text { (Public, } \\
\text { No Ban) }\end{array}$ \\
\hline Intercept & $\begin{array}{c}0.69^{\dagger} \\
(0.028)\end{array}$ & $\begin{array}{c}0.70^{\dagger} \\
(0.036)\end{array}$ & $\begin{array}{c}0.59^{\dagger} \\
(0.068)\end{array}$ & $\begin{array}{c}0.62^{\dagger} \\
(0.080)\end{array}$ & $\begin{array}{r}0.72^{\dagger} \\
(0.12)\end{array}$ \\
\hline Competitive (reference) & - & - & - & - & - \\
\hline Very Competitive & $\begin{array}{c}-0.27^{\dagger} \\
(0.043)\end{array}$ & $\begin{array}{c}-0.25^{\dagger} \\
(0.043)\end{array}$ & $\begin{array}{c}-0.26^{\dagger} \\
(0.043)\end{array}$ & $\begin{array}{c}-0.38^{\dagger} \\
(0.052)\end{array}$ & $\begin{array}{c}-0.15^{*} \\
(0.085)\end{array}$ \\
\hline Highly Competitive & $\begin{array}{c}-0.49^{+} \\
(0.056)\end{array}$ & $\begin{array}{c}-0.47^{+} \\
(0.059)\end{array}$ & $\begin{array}{c}-0.47^{+} \\
(0.059)\end{array}$ & $\begin{array}{c}-0.53^{+} \\
(0.067)\end{array}$ & $\begin{array}{r}-0.52^{\dagger} \\
(0.14)\end{array}$ \\
\hline Most Competitive & $\begin{array}{c}-0.64^{\dagger} \\
(0.064)\end{array}$ & $\begin{array}{c}-0.60^{\dagger} \\
(0.070)\end{array}$ & $\begin{array}{c}0.59^{+} \\
(0.070)\end{array}$ & $\begin{array}{c}-0.68^{\dagger} \\
(0.077)\end{array}$ & $\begin{array}{r}-0.52^{\dagger} \\
(0.19)\end{array}$ \\
\hline Public (reference) & & - & - & & \\
\hline Private & & $\begin{array}{c}-0.085 \\
(0.053)\end{array}$ & $\begin{array}{c}-0.041 \\
(0.055)\end{array}$ & & \\
\hline Nonreligious (reference) & & - & - & - & \\
\hline Non-Catholic Christian & & $\begin{array}{r}-0.0050 \\
(0.055)\end{array}$ & $\begin{array}{c}-0.063 \\
(0.059)\end{array}$ & $\begin{array}{c}-0.066 \\
(0.061)\end{array}$ & \\
\hline Catholic & & $\begin{array}{c}0.078 \\
(0.066)\end{array}$ & $\begin{array}{c}0.049 \\
(0.067)\end{array}$ & $\begin{array}{c}0.038 \\
(0.066)\end{array}$ & \\
\hline State Ban in 2014 & & $\begin{array}{c}0.16^{\dagger} \\
(0.049)\end{array}$ & $\begin{array}{c}0.094 \\
(0.065)\end{array}$ & $\begin{array}{c}-0.11 \\
(0.086)\end{array}$ & \\
\hline Region and/or Court Variables (included?) & $\mathrm{N}$ & $\mathrm{N}$ & Y & Y & Y \\
\hline $\mathrm{R}^{2}$ & 0.20 & 0.23 & 0.25 & 0.30 & 0.27 \\
\hline Adjusted $R^{2}$ & 0.20 & 0.22 & 0.23 & 0.26 & 0.21 \\
\hline$N$ & 589 & 589 & 589 & 383 & 162 \\
\hline
\end{tabular}

a rate 16 percentage points higher than schools in other states. This variable is muted in model 3; it is difficult to completely disentangle regional variation from the presence of state bans. Overall, however, the status variables continue to be substantively very large, and do most of the descriptive work. The additional variables in models 2 and 3 only marginally increase the overall $R^{2}$ (from 0.2 to 0.25 ; adjusted $R^{2}$ from 0.2 to 0.23 ). We also calculated significance levels for the observed differences between the status groups. That is, we tested whether the coefficients were different from each other and not just the reference category. In model 3, Most Competitive and Highly Competitive were significantly different 
from Very Competitive ( $p<0.01$ in both cases), whereas Most Competitive and Highly Competitive were not statistically significantly different from each other $(p=0.11) .{ }^{10}$

Bans have a coercive force for public colleges and universities but only a symbolic one for private schools. Model 4 focuses on just private colleges and universities to see if the patterns are the same for these institutions when considered in isolation from public ones. Model 4 looks very similar to model 3. Again, the status variables do most of the descriptive work, with religion, region, and the ban variable adding relatively little descriptive power. Somewhat surprisingly, the state ban variable has a negative coefficient, implying that private schools in states with bans are less likely to abandon race-conscious admissions, though it is relatively small and not significant.

Model 5 examines public colleges and universities, excluding those in states with bans on the use of race. Because public schools are all secular, this model reduces to regional variables and status. Models 4 and 5 reinforce part of the pattern visible in Figure 5: whereas Very Competitive private colleges and universities were much less likely to abandon than the Competitive reference category, the same is not true for their public counterparts. Very Competitive public colleges and universities abandon at nearly the rate of the Competitive ones, producing the convergence visible in Figure 5.

Together, these models help to characterize the set of colleges and universities that ended their stated commitments to considering race in admissions. The higheststatus schools are the least likely to abandon. Controlling for sector, region, religion, and the presence of a state ban did not change these trends. Lower-status schools (Competitive privates and Competitive and Very Competitive publics), along with those public colleges and universities directly impacted by state bans, were the most likely to stop publicly stating that their admissions process accounted for race.

\section{Discussion and Conclusion}

Our analysis provides empirical evidence for the partial deinstitutionalization of race-conscious admissions over a 25-year time span in the field of selective higher education, stratified across colleges and universities according to their status. As we show, in the early 1990s, affirmative admissions were almost universally endorsed in the top status tiers, were normatively accepted among selective universities, and were increasing in prevalence in the middle- and lower-status tiers. In the mid-1990s, concurrent with the 1994 Hopwood decision that temporarily ended affirmative action in Texas, this institutionalization process halted and reversed direction for selective schools, but not elite ones, over the following two decades.

These transformations are national and largely unexplained by the direct effects of state-level bans on public schools' consideration of race. The bans do explain why two of the three Most Competitive schools ended race-conscious affirmative admissions, yet this serves to highlight that schools in the elite tier remained extremely committed to publicly signaling their attention to race in admissions decisions: only one Most Competitive school (Davidson College) voluntarily abandoned the consideration of race. Looking across all four status tiers, the bans explain at most 
15 percent of the total number of schools that end their stated commitment to race-conscious admissions.

This stratified and partial deinstitutionalization presents puzzles that merit further research. To our knowledge, affirmative action opponents have mobilized little political or legal pressure against individual schools other than the elite schools targeted in high-profile litigation and civil rights complaints. Why would colleges and universities abandon affirmative admissions without direct threats? To answer this question, we must move beyond the politics of the bans themselves to understand the more diffuse impacts of the anti-affirmative action movement as well as the changing legitimacy of race-conscious admissions across the field of higher education. The timing suggests many colleges and universities responded to the growing conservative political backlash rather than to direct challenges or new court decisions. Although public opinion on affirmative action is difficult to measure and depends on question wording, repeated surveys show little movement in this period, suggesting that changes in public opinion are unlikely to explain these field dynamics. ${ }^{11}$ Thus, we interpret the deinstitutionalization of race-conscious admissions policies as a kind of spillover from contestation that directly targeted elite institutions (see Yue et al. 2013).

Prior to the coordinated mobilization of the anti-affirmative admissions movement, middle-status colleges and universities followed their high-status peers. Once that backlash started, those schools quietly backed away from considering race, even as elite schools increased their vocal commitments to diversity in general and to race-conscious admissions in particular. More research, including case studies of the admissions policies of middle- and lower-status schools, is needed to unpack the process. Such research could identify proximate reasons those schools ended their stated use of race-conscious admissions, such as any influence by policy opponents. Those reasons might involve calculations by administrators that race-conscious admissions were not impactful enough to risk an expensive lawsuit, or perhaps the professional norms among admissions staff entailed a less firm commitment to the ideal of diversity (contra Berrey 2015) or techniques of diversity management (contra Lipson 2007). Given the changing demographics of college applicants in some areas, some less elite schools may have determined that they no longer needed to consider race explicitly in order to enroll a sufficient number of students of color to satisfy their diversity imperative.

Our findings also raise questions about the institutional processes that keep elite colleges and universities wedded to race-conscious admissions. As case studies show (Berrey 2015; Warikoo 2016), institutional actors at these schools enforce a symbolic connection between diversity and elitism, coded as meritocracy. They also have greater resources for extensive outreach and attractive scholarships to entice highly competitive students of color. What field-level processes make those practices desirable and beneficial for administrators? Additional investigation into the field-level relationships among schools according to their status and sector could generate insight into the mechanisms that encouraged deinstitutionalization in the bottom tiers of selective institutions but not the top.

Future research should also address the effects of these changes in stated policy. Research on the effects of bans (i.e., stark drop-offs in minority enrollments) has been 
limited to public universities in states with bans (Long and Tienda 2008; Howell 2010; Garces 2012). Thus, it has not captured diffuse effects of the anti-affirmative action movement. We do not know the consequences of voluntary abandonments of race-conscious policies. Do schools' explicit commitments to considering race enable them to enroll a greater proportion of students of color? If quietly abandoning a public commitment to race-conscious admissions has similar effects to the state bans, then scholars may have underestimated the overall impact of conservative backlash. In future research, we plan to directly test the consequences for the racial demographics of the student body when schools end their stated commitment to considering race.

Theoretically, our findings contribute to a growing conversation on race, inequality, and organizations. Processes within both organizations and organizational fields are key elements in the production of inequality. To date, scholarship on race and higher education pays comparatively little attention to nonelite selective colleges and universities in the middle of the organizational field, let alone the dynamics of "lower ed" (Cottom 2017). Yet access to those schools remains an important mechanism for class mobility, class reproduction, and racial stratification (Carnevale and Strohl 2013; Chetty et al. 2017). As scholars increase their attention to organization-level racial dynamics, they should attend to status hierarchies and field-level dynamics in the heterogeneous organizational field of higher education.

\section{Notes}

1 Estimates are based on authors' calculations from ASC and Integrated Postsecondary Education Data System (IPEDS) data; the population and data are described in more detail below.

2 On the role of U.S. News $\mathcal{E}$ World Report and other field-level evaluators of status and reputation in higher education, see Espeland and Sauder 2016 and Bastedo and Bowman 2010.

3 Hopwood applied only to Texas at the time. The two other states in the Fifth Circuit, Louisiana and Mississippi, were still under separate federal orders to desegregate (Shaw 2016).

4 https:/ / studentsforfairadmissions.org/project-on-fair-representation-announces-lawsuitschallenging-admissions-policies-at-harvard-univ-and-univ-of-north-carolina-chapel-hill/. Accessed July 27, 2017.

5 Grodsky and Kalogrides' measure of prestige more closely tracks college and university reputation. Reputation is a continuous measure that emphasizes small differences among organizations based on collective perceptions; each organization is placed "on a continuum from best to worst" as it strives for distinction (Deephouse and Suchman 2008:62). Rankings produced by U.S. News $\mathcal{E}$ World Report most closely match this definition of reputation.

6 See Bastedo and Bowman 2010 and Espeland and Sauder 2016 for extended discussions how organizations strategically manage their self-image through these reports. Also see Colyvas and Jonsson 2011 for a caution against interpreting changes in ubiquity as automatically indicating changes in legitimacy.

7 We use ASC enrollment data for the numerator in these calculations and IPEDS data on total enrollments. Calculations are available on request. 
8 Although status is highly persistent in higher education, the Barron's rankings themselves appear to have undergone some upward drift over the past 25 years (Hess and Hochleitner 2012). That is, there are more schools classified as Most Competitive now than there were in the 1990s because of grade inflation and increased application volumes driving up the apparent selectivity of institutions. Thus, one should not directly compare the Most Competitive category of 2014 with that of 1992. Along with simplicity, this finding motivates our use of a single year's rankings to characterize the field.

9 Results from logistic regression models were similar. We present the linear probability model for its ease of interpretation (see Angrist and Pischke 2009 and Hellevik 2009).

10 In models 1, 2, and 4, the results were similar except that the difference between Most Competitive and Highly Competitive was marginally significant $(0.05<p<0.1)$. In model 5, Most Competitive and Highly Competitive are nearly identical ( $p=0.98)$, Most Competitive and Very Competitive are marginally significantly different $(p=0.066)$, and Highly Competitive and Very Competitive are significantly different $(p=0.013)$.

11 For example, Steeh and Krysan (1996) show roughly constant attitudes over the period of 1970 to 1995 across a range of affirmative action-related attitudes measured in different surveys. Hanson and Zogby (2010) draw from a variety of public opinion surveys to show constant levels of support for affirmative action programs in the period of 1997 to 2008. Newport (2016) shows constant attitudes over the period of 2004 to 2016 in Gallup surveys. Question wordings can strongly influence the level of support, but time series of any particular question show surprisingly little variation during the past 40 years.

\section{References}

Abbott, Andrew. 1998. "The Causal Devolution." Sociological Methods E Research 27(2):148-81. https://doi.org/10.1177/0049124198027002002

Alon, Sigal. 2015. Race, Class, and Affirmative Action. New York: Russell Sage Foundation.

Angrist, Joshua D., and Jörn-Steffen Pischke. 2009. Mostly Harmless Econometrics: An Empiricist's Companion. Princeton: Princeton University Press.

Bastedo, Michael, and Nicholas Bowman. 2010. “U.S. News \& World Report College Rankings: Modeling Institutional Effects on Organizational Reputation." American Journal of Education 116(2):163-83. https ://doi .org/10.1086/649437

Bastedo, Michael N., and Patricia J. Gumport. 2003. “Access to What? Mission Differentiation and Academic Stratification in US Public Higher Education." Higher Education 46(3):341359. https://doi.org/10.1023/A:1025374011204

Berrey, Ellen. 2015. The Enigma of Diversity: The Language of Race and the Limits of Racial Justice. University of Chicago Press. https://doi .org/10.7208/chicago/9780226246376.001. 0001

Bowen, William G., and Derek Bok. 1998. The Shape of the River: Long-Term Consequences of Considering Race in College and University Admissions. Princeton University Press. https://doi.org/10.1515/9781400882793

Carnevale, Anthony, and Jeff Strohl. 2013. Separate \& Unequal: How Higher Education Reinforces Intergenerational Reproduction of White Racial Privilege. Georgetown University Center on Education and the Workforce.

Chetty, Raj, John N. Friedman, Emmanuel Saez, Nicholas Turner, and Danny Yagan. 2017. "Mobility Report Cards: The Role of Colleges in Intergenerational Mobility." National Bureau of Economic Research Working Paper No. 23618. 
Colyvas, Jeannette A., and Stefan Jonsson. 2011. “Ubiquity and Legitimacy: Disentangling Diffusion and Institutionalization." Sociological Theory 29(1):27-53. https : //doi .org/10. $1111 / j .1467-9558.2010 .01386 . x$

Cottom, Tressie McMillan. 2017. Lower Ed: The Troubling Rise of For-Profit Colleges in the New Economy. New York: The New Press.

Deephouse, David L., and Mark Suchman. 2008. “Legitimacy in Organizational Institutionalism." Pp. 49-77 in The SAGE Handbook of Organizational Institutionalism, edited by Royston Greenwood, Christine Oliver, Kerstin Sahlin, and Roy Suddaby. Thousand Oaks, CA: Sage Publications. https://doi.org/10.4135/9781849200387.n2

Espeland, Wendy Nelson, and Michael Sauder. 2016. Engines of Anxiety: Academic Rankings, Reputation, and Accountability. New York, New York: Russell Sage Foundation.

Espenshade, Thomas J., Chang Y. Chung, and Joan L. Walling. 2004. "Admission Preferences for Minority Students, Athletes, and Legacies at Elite Universities." Social Science Quarterly 85(5):1422-1446. https://doi.org/10.1111/j.0038-4941.2004.00284.x

Garces, Liliana M. 2012. "Racial Diversity, Legitimacy, and the Citizenry: The Impact of Affirmative Action Bans on Graduate School Enrollment." The Review of Higher Education 36(1):93-132. https://doi .org/10.1353/rhe.2012.0050

Grodsky, Eric. 2007. "Compensatory Sponsorship in Higher Education." American Journal of Sociology 112(6):1662-1712. https : //doi .org/10.1086/512707

Grodsky, Eric, and Demetra Kalogrides. 2008. "The Declining Significance of Race in College Admissions Decisions." American Journal of Education 115(1):1-33. https : //doi .org/10. $1086 / 590673$

Hanson, Sandra, and John Zogby. 2010. "Trends: Attitudes About the American Dream." The Public Opinion Quarterly 74(3):570-84. https ://doi .org/10.1093/poq/nfq010

Hellevik, Ottar. 2009. "Linear versus Logistic Regression When the Dependent Variable Is a Dichotomy." Quality $\mathcal{E}$ Quantity 43(1):59-74. https://doi.org/10.1007/ s11135-007-9077-3

Hess, Frederick, and Taryn Hochleitner. 2012. "College Rankings Inflation: Are You Overpaying for Prestige?" Washington, DC: American Enterprise Institute for Public Policy Research. Retrieved August 9, 2017. http://www.aei.org/publication/ college-rankings-inflation-are-you-overpaying-for-prestige/

Hirschman, Daniel, Ellen Berrey, and Fiona Rose-Greenland. 2016. "Dequantifying Diversity: Affirmative Action and Admissions at the University of Michigan." Theory and Society 45(3):265-301. https://doi.org/10.1007/s11186-016-9270-2

Howell, Jessica S. 2010. "Assessing the Impact of Eliminating Affirmative Action in Higher Education." Journal of Labor Economics 28(1):113-66. https : //doi . org/10 . 1086/648415

Karabel, Jerome. 2005. The Chosen: The Hidden History of Admission and Exclusion at Harvard, Yale, and Princeton. Houghton Mifflin Harcourt.

Kelly, Erin, and Frank Dobbin. 1998. "How Affirmative Action Became Diversity Management Employer Response to Antidiscrimination Law, 1961 to 1996." American Behavioral Scientist 41(7):960-84. https : //doi .org/10.1177/0002764298041007008

Levitsky, Sandra, and Elizabeth Armstrong. 2017. “Leaders and Laggards: Understanding University Responses to Sexual Violence in a Changing Legal Environment." Paper presented at the Annual Meeting of the Law and Society Association, Mexico City.

Lipson, Daniel N. 2001. “Affirmative Action as We Don't Know It: The Rise of Individual Assessment in Undergraduate Admissions at UC-Berkeley and UT-Austin." Pp. 137-84 
in Studies in Law, Politics, and Society volume 23, edited by Austin Sarat and Patricia Ewick. Greenwich, CT: JAI Press. https://doi.org/10.1111/j.1747-4469.2007.00085.x

Lipson, Daniel N. 2007. "Embracing Diversity: The Institutionalization of Affirmative Action as Diversity Management at UC-Berkeley, UT-Austin, and UW-Madison." Law E Social Inquiry 32(4):985-1026.

Long, Mark C., and Marta Tienda. 2008. “Winners and Losers: Changes in Texas University Admissions Post-Hopwood." Educational Evaluation and Policy Analysis 30(3):255-80. https : //doi.org/10.3102/0162373708321384

Meyer, John, and Brian Rowan. 1977. "Institutionalized Organizations: Formal Structures as Myth and Ceremony." American Journal of Sociology 83(2):340-63. https : //doi .org/10. $1086 / 226550$

Newport, Frank. 2016. "Most in U.S. Oppose Colleges Considering Race in Admissions." Gallup.com. Retrieved June 1, 2017. http://www.gallup.com/poll/193508/ oppose-colleges-considering-race-admissions .aspx.

Okechukwu, Amaka. Forthcoming. To Fulfill These Rights: Political Contention over Affirmative Action in Public Universities. New York, NY: Columbia University Press.

Oliver, Christine. 1992. "The Antecedents of Deinstitutionalization." Organization Studies 13(4):563-88. https://doi.org/10.1177/017084069201300403

Posselt, Julie Renee, Ozan Jaquette, Rob Bielby, and Michael N. Bastedo. 2012. “Access without Equity Longitudinal Analyses of Institutional Stratification by Race and Ethnicity, 1972-2004." American Educational Research Journal 49(6):1074-1111. https : //doi . org/10. 3102/0002831212439456

Scott, W. Richard. 2013. Institutions and Organizations: Ideas, Interests, and Identities volume 4. Thousand Oaks, CA: Sage Publications.

Shaw, Matthew Patrick. 2016. "Bans on Affirmative Action in States with a History of State-Sponsored Discrimination." Pp. 174-189 in School Integration Matters, edited by Erica Frankenberg, Liliana M. Garces, and Megan Hopkins. New York, NY: Teachers College Press.

Skrentny, John D. 2002. The Minority Rights Revolution. Cambridge, MA: Belknap Press.

Steeh, Charlotte, and Maria Krysan. 1996. "Trends: Affirmative Action and the Public, 19701995." The Public Opinion Quarterly 60(1):128-58. https : //doi .org/10. 1086/297742

Stevens, Mitchell L., Elizabeth A. Armstrong, and Richard Arum. 2008. "Sieve, Incubator, Temple, Hub: Empirical and Theoretical Advances in the Sociology of Higher Education." Annual Review of Sociology 34(1):127-51. https://doi.org/10.1146/annurev.soc. 34 . 040507.134737

Stulberg, Lisa M., and Anthony S. Chen. 2014. "The Origins of Race-Conscious Affirmative Action in Undergraduate Admissions A Comparative Analysis of Institutional Change in Higher Education." Sociology of Education 87(1):36-52. https://doi .org/10.1177/ 0038040713514063

Suchman, Mark C. 1995. "Managing Legitimacy: Strategic and Institutional Approaches." Academy of Management Review 20(3):571-610.

Warikoo, Natasha K. 2016. The Diversity Bargain. Chicago, IL: University of Chicago Press. https://doi.org/10.7208/chicago/9780226400280.001.0001

Yue, Lori Qingyuan, Hayagreeva Rao, and Paul Ingram. 2013. “Information Spillovers from Protests against Corporations: A Tale of Walmart and Target." Administrative Science Quarterly 58(4):669-701. https://doi.org/10.1177/0001839213511243 
Acknowledgements: We thank Prabhdeep Kehal for his excellent research assistance and instructive comments. Mikaila Mariel Lemonik Arthur, Ronit Dinovitzer, Steve Hoffman, Ashley Rubin, and Terri Taylor provided feedback that improved this article. Research funding was provided by Brown University's Program in Business, Entrepreneurship and Organizations.

Daniel Hirschman: Department of Sociology, Brown University.

E-mail: daniel_hirschman@brown.edu.

Ellen Berrey: Department of Sociology, University of Toronto.

E-mail: ellen.berrey@utoronto.ca. 